\title{
MASYARAKAT UTOPIS DAN DISTOPIS DALAM TEKS THE ONES WHO WALK AWAY FROM OMELAS, KARYA URSULA LE GUIN
}

\author{
Mita Rosaliza, Essy Syam \\ Universitas Riau \\ Universitas Lancang Kuning \\ mita.rosaliza@lecturer.unri.ac.id \\ essysyam@unilak.ac.id
}

\begin{abstract}
This writing analyzes a short story entitles The Ones Who Walk Away From Omelas written by Ursula Le Guin which highlights the elements of Utopia and Dystopia found in a society as reflected in the text such as the happiness, cheerfulness which are almost perfect. Besides, the feeling of secure is also felt by the inhabitants of Omelas so that they don't need a government to manage their life. On the contrary, the element of dystopia is ironic, in which the happiness felt by the people is paid by a little child who is locked in dark, small room. This child is victimized to guarantee the perfect life of the people in Omelas. Consequently, those who can't accept this reality decide to leave Omelas, they are the ones who walk away from Omelas. Related to that, this analysis applies descriptive analysis in which the result will be explained descriptively. From the description, it will show how the elements of Utopia and Dystopia are reflected in the life of the people in Omelas which describe the society of Omelas and its belief in Sacrificing the child for the sake of the happiness of the community.

Keywords: Utopia, Dystopia, The Ones Who walk Away From Omelas, Ursula Le Guin.

\section{PENDAHULUAN}

Tatanan masyarakat dapat terbentuk dari kumpulan keinginan dan harapan warganya. Idealnya warga masyarakat menginginkan hidup dalam tatanan masyarakat yang baik tanpa kekurangan.

Mereka menginginkan suatu
tatanan masyarakat yang
sempurna dalam segala aspek
kehidupan. Tatanan masyarakat
seperti itu hampir mustahil
terwujud karena dalam kehidupan
manusia tidak ada yang sempurna.
\end{abstract}


Pada kenyataannya ketidaksempurnaan bahkan lebih banyak dari kesempurnaan. Kesempurnaan tatanan masyarakat dalam segala aspek kehidupan hanyalah sebuah mimpi yang sulit terwujud bahkan hanya sebuah khayalan. Walau demikian, dalam kehidupan-nya manusia selalu berupaya untuk mendapatkan kesempurnaan itu. Masyarakat impian serupa itu dise-but juga dengan masyarakat utopis.

Bertentangan dengan utopis, masyarakat distopis merupakan masyarakat yang tidak didambakan karena masyarakat distopia adalah masyarakat yang buruk dan mena-kutkan karena dalam masyarakat ini ditemukan banyak hal-hal yang buruk seperti pemerintah yang diktator, bencana lingkungan, ke-merosotan moral, kesulitan eko-nomi, dan hal-hal buruk lainnya yang menimbulkan kesulitan bagi warganya. Dalam masyarakat dis-topis ditemukan tatanan masyarakat yang bobrok yang menempatkan warganya dalam kehidupan yang sulit dan tidak menyenangkan bahkan adapula yang menyajikan kehidupan yang menyedihkan bagi warganya.
Utopia dan distopia merupakan dua hal yang sangat berbeda, bahkan bertolak belakang. Karena keduanya merupakan hal yang bertentangan, tentu saja keduanya tidak dapat disatukan dalam satu keadaan. Namun ternyata unsurunsur dari kedua hal ini dapat ditemukan dalam satu keadaan dan satu masyarakat yang sama. Oleh karena itu, hal yang demikian menjadi suatu yang menarik untuk dicermati lebih lanjut.

Terkait dengan hal di atas, tulisan ini akan menganalisis unsurunsur utopia dan distopia yang mencerminkan masyarakat yang utopis dan distopis pada sebuah cerita pendek berjudul The Ones Who Walk Away From Omelas yang ditulis oleh Ursula le Guin dengan tujuan memperoleh gambaran kedua hal tersebut dari teks cerpen Ursula ini.

\section{TINJAUAN PUSTAKA}

\section{A. Utopia ( Utopis)}

Kata utopia pertama kali digunakan oleh Sir Thomas More dalam karyanya yang berjudul Utopia yang diterbitkan pada tahun 1516 . Kata utopia memiliki kesamaan dalam bahasa Yunani autopos yang berarti tempat "yang baik." Dalam karyanya, Thomas More meng- 
gambarkan visinya tentang sebuah masyarakat yang ideal, yang hampir mustahil ditemukan dalam kehidupan manusia.

Kata "utopia" merupakan oposisi biner dari kata "dystopia." Thomas More, seorang pemikir Inggris yang hidup di jaman Renaissance akhir, pada tahun 1515 menulis tentang "Utopia," yang dipublikasikan ke publik pada tahun 1516. "Utopia" merupakan gagasan tentang masyarakat ideal yang tatanannya berdasarkan "alasan." More sebenarnya membayangkan visi masyarakat egalitarian yang relasi sosialnya didasari oleh rasionalitas dan konsensus-konsensus bersama. Gambaran yang sangat ideal ini pada masa itu merupakan hal yang sulit untuk dibayangkan. More menggambarkan bahwa dalam tatanan tersebut masyara-kat yang terdiri dari tujuh bagian hidup saling menghormati (toleran satu sama lain) melalui nilai- nilai yang disepakati dan dijunjung ber-sama. Masyarakat egalitarian yang digambarkan More lebih mirip dengan masyarakat komunis yang dibayangkan Marx. Itu sebabnya ide masyarakat bebas kelas yang dicita-citakan Marx dianggap sebagai Utopia. (Mangoenkoesoemo,2012 dalam http://culturalidiot.blogspot. co.id/2012/06/utopiaheterotopiarevisiting-michel.html)

Karya sastra yang termasuk dalam kategori utopia dan distopia mengeksplorasi struktur sosial dan politik. Banyak karya-karya yang menggabungkan tatanan masyarakat yang utopis dan distopis dalam karya sastra sebagai metafora yang menggambarkan kemanusian yang menempuh jalan yang berbeda-beda yang akan menuju masa depan yang berbeda pula.

\section{B. Distopia (Distopis)}

Distopia merujuk pada sebuah masyarakat yang dicirikan dengan ciri-ciri yang bertolak belakang den-gan masyarakat utopis. Masyara-kat distopia digambarkan dengan masyarakat yang mengalami ke-miskinan yang merata, kecurigaan dan ketidakpercayaan publik dan penindasan.

Masyarakat distopia men-yindir apa yang terjadi dalam masyarakat dimana kriminal dibela dan yang benar dihukum. Karena menggambarkan kondisi masyarakat, karya seperti ini dapat menjadi sarana politis.

Kata distopia diciptakan sebagai antonim dari makna utopia. Distopia berkembang untuk menyebutkan "tempat khayalan yang 
buruk." (https://id.wikipedia.org/ wiki/ Distopia). Distopia (distopis) merupakan suatu komunitas atau masyarakat yang tidak didambakan atau yang menakutkan, yang diterjemahkan sebagai "tempat yang tidak baik". Bertolak belakang dari utopia yang menampilkan suatu masyarakat yang ideal tanpa kejahatan atau kemiskinan, distopia menampilkan masyarakat dengan dehumanisasi dengan kemerosotan nilai secara dahsyat dalam masyarakat. Bentuk dehumanisasi dalam masyarakat distopia dapat ditemukan dalam berbagai aspek seperti lingkungan, politik, ekonomi, agama, psikologi, etika, ilmu, teknologi dan lain sebagainya.

\section{METODE PENELITIAN}

Kajian ini menganalisis sebuah karya sastra berjudul The Ones Who Walk Away From Omelas den-gan memfokuskan pada unsur-unsur utopia dan distopia yang tercermin dari gambaran masyarakat dalam karya ini. Kajian ini merupakan sebuah studi kepustakaan dimana kajian dilakukan dengan mengum-pulkan data-data kepustakaan.

Tahap pertama penelitian ini dilakukan dengan mengidentifikasi adanya unsur-unsur utopia dan distopia dalam teks. Tahap kedua adalah menganalisis unsurunsur utopia dan distopia tersebut. Kajian ini merupakan suatu analisis deskriptif analisis yang bertujuan menggambarkan fenomena yang ada. Kajian ini akan mendeskripsikan unsur-unsur utopia dan distopia yang secara bersamaan mencerminkan masyarakat yang utopis dan distopis Selanjutnya, dalam mengumpulkan hasil kajian, kesimpulan ditarik secara induktif dimana gambaran-gambaran spesifik yang dipaparkan menuntun pada gambaran umum tentang kajian tersebut.

\section{HASIL DAN PEMBAHASAN}

Unsur-unsur utopia dan distopia yang tercermin dalam teks The Ones Who Walk Away From Omelas terlihat dari beberapa kejadian yang memperlihatkan bahwa kedua unsur tersebut dapat ditemukan dalm teks cerpen ini.

Unsur-unsur utopia tergambar dari kebahagiaan, keceriaan dan kemeriahan kehidupan warga Omelas. Hal ini ditampilkan disaat mereka merayakan festival musim panas. Selain itu kesempurnaan hidup mereka juga didukung oleh ketenangan dan keamanan yang mereka alami dalam kehidupan mereka sehingga warga Omelas tidak memerlukan suatu pemerintahan untuk mengatur kehidupan mereka. 
Sebaliknya, kehidupan warga Omelas yang sempurna itu ternyata mereka jalani dengan mengorbankan seorang anak kecil sebagai tumbal. Anak kecil itu mereka kurung di salah satu ruang bawah tanah kota. Mereka percaya jika tidak ada anak kecil yang dikurung di ruang bawah tanah maka kesempurnaan kehidupan mereka pun akan lenyap. Dengan alasan itulah maka warga Omelas harus merasa tega mempertaruhkan nasib seorang anak demi kebaikan penduduk kota.

Sebagian warga Omelas yang tidak dapat menerima kondisi ini memutuskan pergi meninggalkan Omelas walau tanpa tujuan. Tindakan penduduk kota yang mempertaruhkan kehidupan seorang anak tidak berdosa demi kehidupan indah mereka sungguh tidak dapat mereka terima.

Gambaran masyarakat utopis dalam The One Who Walk Away From Omelas

\section{Suasana Kegembiraan Yang Sempurna}

Suasana di Omelas sangat menyenangkan. Orang-orang di sana merayakan sebuah festival musim panas. Kota Omelas dihiasi seindah mungkin untuk memperlihatkan betapa keindahan dan kemeriahan begitu sempurna dirasakan oleh seluruh penduduk kota. Suara lonceng terdengar hingga ke penjuru kota, kapal-kapal di pelabuhan terlihat bersinar, penuh dengan bendera warna -warni. Di antara rumahrumah beratap merah dan tembok berwarna, kebun-kebun kecil dan bawah pohon, juga di antara taman besar dan gedung- gedung umum, jalanan penuh oleh arak-arakan.

With a clamor of bells that set the swallows soaring, the festi-val of Summer came to the city Omelas, bright tower of the sea. The ringing of the boats in harbor sparkled with flags. In the street between houses with red roofs and painted walls, between old mossgrown gardens and under avenues of trees, past great parks and public buildings, procession moves. (Le Guin, 1973: 1)

Kemeriahan festival di lengkapi dengan arak-arakan orang berhias, orang-orang tua memakai jubah panjang keabuan, para pekerja ku-buran penuh ketenangan, para ibu menggendong bayi dan berbincang sambil berjalan. Semua tampak menikmati kegembiraannya, "Some were decorous: old people in long stiff robes or mauve and grey, grave master workmen, quiet, merry women carrying thier babies and chatting as they walk. (Le Guin, 1973: 1) 
Kemeriahan ini makin disemarakkan oleh suara musik dengan hentakan yang cepat diiringi suara gong dan tamborin yang menyemangati para penari di bagian jalan yang lain, "in other streets, the music beat faster, a shimmering of gong and tambourine, and the people went dancing, the procession was a dance. (Le Guin, 1973:1)

Festival membuat orang-orang bergembira. Suasana penuh kegembiraan ini semakin semarak dengan adanya kuda-kuda yang mengiringi pejalan kaki dalam arak-arakan yang penuh suka cita. Sepanjang arah ke utara dan barat, bukit-bukit melingkari Omelas. Suasana keriangan ini makin terasa didukung pula dengan udara pagi yang segar, dengan salju yang masih bertengger di puncak bukit. Kembang api berwarna keemasan turut juga menghiasi langit Omelas. Angin yang berhembus dengan lembut me-niup banner-banner yang dipasang sepanjang jalan.

They were vastly excited, the horse being the only animal who has adopted our ceremo-nies as his own. Far off to the north and west, the mountains stood up half encircling Omelas on her bay. The air of morning was so clear that the snow still crowning the Eighteen peaks burned with white -gold fire across the miles of sunlit air, under the dark blue of the sky. There was just enough wind to make the banners that marked the racecourse snap and flatter now and then. (Le Guin, 1973: 1)

Gambaran kemeriahan dan keceriaan yang tergambar di atas, menyempurnakan kebahagiaan yang dirasakan oleh penduduk kota Omelas. Kebahagiaan ini terwujud dari kegembiraan mereka dalam menikmati festival musim panas saat itu.

\section{Kota Yang Aman}

Selain kebahagiaan yang mereka rasakan, kebahagiaan penduduk Omelas makin sempurna dengan kehidupan yang aman dan tenang. Begitu amannya dan tenangnya kehidupan di Omelas sehingga Omelas tidak perlu memiliki pemimpin. Orang-orang di Omelas tidak perlu menggunakan pedang atau senjata lainnya. Selain itu kehidupan mereka sangat mudah sehingga mereka tidak memerlukan budak untuk menyelesaikan kebutuhan hidup, " but there was no king. They did not use swords, or keep slaves." (Le Guin, 1973: 2 )

Keamanan dan ketenangan kota Omelas ini diperlihatkan dari tidak 
adanya aturan hidup atau hukum yang mengatur kehidupan mereka. Kehidupan yang tidak memerlukan aturan ini juga tidak memerlukan hal-hal pendukung hidup lainnya seperti stock exchange, iklan, dan mereka bahkan tidak memerlukan polisi rahasia dan lainnya. Kehidupan yang sangat aman ini juga ditunjukkan dari kenyataan bahwa Omelas tidak memerlukan bom yang mengindikasikan kriminalitas atau kejahatan sejenisnya, "as they did without monarchy and slavery, so they also got on without the stock exchange, the advertisement, the secret police and bomb." (Le Guin, 1973: 2)

Kehidupan yang tenang, aman dan menyenangkan yang digambarkan tentang penduduk kota Omelas ini memperlihatkan kehidupan yang sempurna (utopis), kehidupan yang hampir mustahil dirasakan.

\section{Gambaran Masyarakat Distopis dalam The One Who Walk Away From Omelas}

\section{Mengorbankan Seseorang}

Dibalik kesempurnaan dan kebahagiaan hidup yang dijalani oleh penduduk Omelas, ternyata menyimpan sisi gelap. Di balik kebahagiaan mereka, ternyata ada seseorang yang dikorbankan. Di bawah sebuah bangunan yang indah di Omelas, terdapat ruangan kecil tanpa jendela yang terkunci dan berlantai kotor. Di sudut ruangan itu meringkuk seorang anak kecil berumur 10 tahun.

In a basement under one of the beautiful public buld-ings of Omelas, or perhaps in the cellar of one of its spacious private homes, there is a room. It has one locked door, and no window. A little light seeps in dustily between cracks in the boards, secondhand from

a cobwebbed window somewhere across the cellar. In one corner of the littel rooma couple of mops, with stiff, clot-ted, foul-smelling heads, stand near a rusty bucket. The floor is dirt, a little damp to the touch, as cellar dirt usually is. The room is about three paces long and two wide: a mere boom closetor disused tool room. In the room, a child is sitting. (Le Guin, 1973: 2)

Ruangan itu kecil dan pengap, terlihat seperti sebuah ruangan untuk menyimpan alat-alat kebersihan. Sangat tidak memadai untuk ditempati apalagi bagi seorang anak kecil. Namun, disitulah bocah malang itu dikurung. Kondisi si anak sangat menyedihkan sehingga ia terlihat sangat kecil, lebih kecil 
dari usianya. Dia berumur sepuluh tahun tapi terlihat seperti anak berumur enam tahun, "it looks about six, but actually is nearly ten." (Le Guin, 1973: 2)

Anak kecil itu dikurung dan diperlakukan tidak manusiawi. Orang-orang di Omelas tidak menganggapnya sebagai manusia namun sebagai objek sehingga dalam menggambarkannya digunakan kata it yang merupakan kata ganti untuk menunjukkan benda atau hewan, “ It could be a boy or a girl. It looks about six, but actually is nearly ten." (Le Guin, 1973: 2 )

Dikurung dalam ruangan kecil terkunci bisa jadi salah satu penyebab si anak merasa ketakutan, kekurangan gizi dan merasa terbuang. Ia tumbuh jadi anak berpikiran lemah, anak yang cacat, "It is feeble-minded. Perhaps it was born defective or perhaps it has become imbecile through fear, malnutri-tion and neglect."(Le Guin, 1973:

2) Kelemahan pikirannya bisa jadi disebabkan oleh ketakutan. Mentalnya tertekan, tapi tak ada siapa pun yang menolong, "and the door is locked; and nobody will come." Ia sangat takut pada alat pengepel namun alat itu seolah sengaja diletakkan di dalam ruangan tempat ia dikurung. Ia mencoba menjauh dari alat pengepel, mencoba menjauh dari ketakutan yang menghantuinya. Ia meringkuk di sudut ruangan. Seorang diri dalam kegelalapan dan kepengapan. Ia tutup matanya berharap alat pengepel itu hanya mimpi dan segera hilang ketika ia membuka mata. Tapi, tidak ada yang hilang. Alat pengepel itu tetap berada di situ, menekan-nekan men-talnya, mengaduk-aduk kewarasan-nya. " it is afraid of the mops. It finds them horrible. It shuts its eyes, but it knows the mops are still stand-ing there" (Le Guin, 1973: 2). Si bocah malang disiksa secara fisik dan mental hingga ia mengalami kemunduran kemampuan berpikir.

Penduduk Omelas mengetahui tentang anak kecil dan pengurungan itu, bahkan mereka tahu tempatnya. Sebagian datang melihatnya, namun mereka malah memperlakukannya dengan buruk. Mereka yang datang itu, ada yang menendang agar si anak berdiri, ada juga yang takut untuk mendekat, ada yang mengintip dengan mata ketakutan dan rasa jijik, "one of them may come and kick the child to make it stand up. The others never come close, but peer at it with frightened, disgusted eyes." ( (Le Guin, 1973: 4 )

Anak itu terkurung dalam waktu yang lama sehingga ia tidak 
berkomunikasi dengan siapapun. Orang-orang yang datang melihatnya tidak berniat berkomunikasi, mereka datang hanya karena rasa penasaran bukan karena perhatian. Karena lama tidak berkomunikasi, si anak hanya mampu mengingat beberapa kalimat yang sering ia ucapkan ketika ia ingin keluar dari kurungan itu.

The people at the door never say anything, but the child, who has not always lived in the tool room, and can remember sunlight and it's mother's voice, sometimes speaks, "I will be good," it says." Please let me out. I will be good!" they never answer." (Le Guin, 1973: 5 ) Petikan ini memperlihatkan betapa kurungan itu begitu menyakitkan sehingga ia meminta tolong agar dikeluarkan dari tempat itu, namun tidak ada yang peduli. Ia memo-hon agar orang-orang yang datang melihat menolongnya dan mengeluarkannya dari ruangan sempit itu, namun tidak ada yang merasa tergerak hatinya untuk menolong. Permohonannya yang memelas tidak menyentuh hati orang-orang Omelas.

Apa yang dirasakan anak itu di malam hari sungguh lebih menyedihkan lagi. Dalam malam gelap lagi dingin yang membuatnya menggigil dan semakin takut, ia berteriak dan menjerit dengan tangis meminta pertolongan, " the child used to scream for help at night, and cry a good deal. "(Le Guin, 1973: 5). Namun, walau telah berulang-ulang melakukannya, tetap tidak ada yang peduli. Jeritan dan tangisnya tak menyentuh hati siapapun. Ia putus asa dan tidak pernah lagi melakukannya. Intensitas komunikasinya semakin berkurang. Ia makin sedikit berbicara sehingga hampir melupakan ekspresi-ekspresi dalam komunikasi, "but now, it only makes a kind of whining, " eh-haa, eh-haa, " and it speaks less and less often."(Le Guin, 1973: 5)

Kurungan itu memberikan pengaruh yang sangat buruk terhadap kondisi kejiwaannya. Secara fisik pun kondisinya pun menyedihkan. Dia begitu kurus hingga tidak ada betis di kakinya, perutnya buncit, sehari dia hanya mengonsumsi separuh mangkuk sereal jagung dan lemak. Dia telanjang. Pantat dan pahanya dipenuhi nanah karena dia sering kali duduk di atas kotorannya sendiri, " it is so thin there are no calves to its legs: its belly petrudes; it lives on a half bowl of corn meal and grease a day. It is naked. Its buttocks and thighs are a mass of festered sores, as it sits in its own 
excrement continually." (Le Guin, 1973: 5)

Penduduk Omelas sangat menyadari penderitaan anak dalam kurungan itu. Mereka semua tahu, beberapa dari mereka telah datang untuk melihatnya, yang lain cukup puas dengan hanya mengetahui dia ada di sana. Mereka semua tahu bahwa dia harus berada di sana. Beberapa dari mereka paham alasannya, dan beberapa tidak, namun mereka semua mengerti bahwa kebahagiaan mereka, keindahan kota mereka, kelembutan persahabatan mereka, kesehatan anak-anak mereka, kebijaksanaan para kaum terpelajar mereka, kemampuan para pencipta mereka, bahkan kelimpahan dari panen mereka dan kebaikan cuaca dari langit mereka bergantung sepenuhnya pada kesengsaraan dan nasib buruk si anak. Mereka meya-kini bahwa anak malang itu harus dikorbankan demi kebahagiaan dan kesejahteraan mereka.

They all know it is there, all the popel of Omelas. Some of them have come to see it, others are content merely to know it is there. They all know that it has to be there. Some of them understand why, and some do not, but they all understand that their happiness, the beauty of their city, the tender- ness of their friendships, the health of their children, the wisdom of their scholars, the skills of their makers, even the abundance of their harvest and the kindly weathers of their skies, depend wholly on this child's abominable misery. (Le Guin, 1973:5)

Penduduk Omelas meyakini kebahagiaan dan kelanjutan hidup mereka bergantung pada penderitaan yang dialami anak kecil ini. Mer-eka percaya harus ada seseorang yang dikorbankan agar kesejahter-aan dapat diraih. Anak itu akhirnya serupa tumbal demi kepentingan orang lain. Dengan menyadari pentingnya keberadaan anak itu, penduduk Omelas selalu mem-beritahukan tentang keberadaan-nya kepada anak-anak mereka. Di saat anak-anak mereka berumur delapan sampai sebelas tahun, disaat mereka dianggap sudah dapat memahami, maka orang tua mereka akan menceritakan tentang keberadaan anak itu. Karena itulah sebagian besar yang datang untuk melihat si anak kecil adalah para anak muda yang penasaran tentang keberadaannya. Walaupun anakanak muda itu telah memperoleh gambaran kondisi si anak dari cerita orang tua mereka, namun ketika melihat secara langsung, mereka ru- 
panya tetap mengalami keterkejutan dan merasa jijik, "No matter how well the matter has been explained to them, these young spectators are always shocked and sickened at the sight. They feel disgust, which they had thought themselves superior to, “(Le Guin, 1973: 5 )

Melihat kondisi anak kecil itu yang sangat menyedihkan, tidak sedikit anak-anak muda yang merasa kasihan dan tersentuh. Mereka ingin menolongnya, tapi urung. Jika mer-eka menolong dengan membawa anak kecil itu keluar dari tempat kurungannya mereka meyakini hal itu dapat melenyapkan semua kebahagiaan dan kesenangan yang mereka rasakan. Jadi menyelamat-kan si anak kecil dari kurungannya berarti mempertaruhkan kehidupan nyaman semua warga Omelas.

If the child were brought up into the sunlight out of that vile place, if it were cleaned and fed and comforted, that would be a good thing, indeed; but if it were done, in that day and hour all the prosperity and beauty and delight of Omelas would wither and be destroyed. Those are the terms. To exchange all the goodness and grace of every life on Omelas for that single, small improvement; to throw all the happiness of thousands for the chance of the happiness of one. (Le Guin, 1973: 6 )
Dengan keyakinan ini, maka mereka tidak dapat menolong anak kecil itu. Mereka merasa lebih baik mengorbankan hidup seorang anak untuk menyelamatkan hidup lebih banyak orang. Walaupun mereka dapat menerima alasan ini, namun mereka merasa marah terhadap diri sendiri karena ketidakberdayaan mereka meyelamatkan si anak. Mereka merasa menjadi orang yang biadab karena membiarkan penderitaan tetap di depan mata. Karena itulah, setelah mengunjungi anak kurungan itu, sering mereka pulang ke rumah dengan air mata bercucuran. Mereka meratapi nasib si anak dalam waktu yang cukup lama. Namun, mereka lalu menyadari ka-laupun anak itu dilepaskan, ia juga tidak mendapatkan hal yang baik dari kebebasannya. Anak itu hanya dapat merasakan kesenangan kecil seperti kehangatan dan makanan. Dia tidak dapat hidup normal karena ia cacat dan idiot. Anak itu sudah terlalu lama hidup dalam ketakutan sehingga ia hidup dengan cara yang sembrono dan tidak terbiasa mere-spon dengan baik. Paling tidak ini-lah yang dapat mereka jadikan ala-san untuk menenangkan hati mereka dari rasa bersalah. Walaupun alasan 
ini terasa dipaksakan demi semata mengurangi rasa bersalah mereka.

Walaupun mereka menciptakan alasan-alasan, namun tidak semua melakukan hal yang sama. Sebagian anak remaja yang tidak dapat menerima perlakuan buruk terhadap anak kecil itu tidak menunjukkan rasa kasihan dengan menangis atau mengungkapkan kemarahan karena mereka menyadari hal itu tidak akan berguna. Lalu mereka memutuskan pergi dan tidak pernah kembali ke rumah, "At times, one of the ado-lescent girls or boys who go to see the child does not go home to weep or rage, does not in fact, go home at all." ( Le Guin,1973: 7 ) Apa yang mereka lakukan ini memperlihatkan betapa mereka juga turut merasa tersiksa atas apa yang dialami si anak kecil, dikurung di tempat yang tidak layak selama bertahun-tahun.

Selain anak-anak remaja yang pergi meninggalkan Omelas, orangorang dewasapun melakukan hal yang sama. Sebagian penduduk Omelas yang melihat keadaan anak kecil itu merasa sangat terpukul, mereka tidak dapat berkata- kata, terdiam selama satu atau dua hari, lalu pergi meninggalkan Omelas, "+Sometimes also a man or woman much older falls silent for a day or two, and then leaves home." (Le Guin, 1973: 7).
Alasan kepergian orang-orang ini sama dengan alasan kepergian anak-anak remaja itu. Hati nurani mereka tidak bisa me-nerima tindakan biadab dan tidak manusiawi terhadap bocah malang dalam kurungan, namun mereka tidak bisa berbuat apa-apa. Mereka ti-dak berdaya terhadap apa yang telah diyakini bersama oleh penduduk Omelas. Lebih baik mengorbankan seorang saja daripada melenyapkan kebahagiaan orang banyak. Mereka akhirnya memilih pergi walaupun mereka tidak tahu kemana tujuan, yang ada dalam pikiran mereka hanyalah pergi meninggalkan Om-elas sejauh mungkin. Mereka terus berjalan, siang dan malam, mele-wati dusundusun dan desa-desa, dalam kegelapan malam. Ada yang berjalan ke arah Barat, ada pula yang ke arah Utara, ke arah gunung-gunung. Mereka terus berjalan dan tidak akan kembali lagi ke Omelas. Mereka merasa pasti dengan lang-kah mereka, meninggalkan Omelas.

These people go out into the street, and walk down the street alone. They keep walking and walk straight out of the city of Omelas, through the beauti-ful gates. They keep walking across the farmland of Omelas. Each one goes alone, youth or girl, man or woman. Night falls: the traveler must pass down vil- 
lage streets, between the houses with yellow-lit windows, and on out into the darkness of the fields. Each alone, they go west or north, towards the mountains. They go on. They leave Omelas, they walak ahead into the darkness, and they do not come back. The place they go towards is a place even less imaginable to most of us than the city of happiness. I can not describe it at all. It is possible that it does not exist. But they seem to know where they are going, the ones who walk away from Omelas. (Le Guin, 1973: 7)

\section{SIMPULAN}

Terdapat dua unsur yang mencerminkan masyarakat utopis dalam teks The Ones Who Walk Away From Omelas. Yang pertama, suasana di Omelas yang sangat menyenangkan. Orang-orang di Omelas merayakan sebuah festival musim panas. Untuk memperlihatkan betapa keindahan dan kemeriahan begitu sempurna dirasakan penduduk kota, maka Omelas di hiasi seindah mungkin. Gambaran masyarakat utopis yang kedua adalah keadaan kota Omelas yang aman. Selain kebahagiaan yang mereka rasakan, kehidupan penduduk Omelas makin sempurna dengan kondisi kota yang aman dan tenang. Begitu aman dan tenangnya kehidupan di Omelas sehingga Omelas tidak perlu memiliki pemimpin. Orang-orang di Omelas juga tidak perlu menggunakan pedang atau senjata lainnya. Sebaliknya, teks The Ones Who Walk Away From Omelas ini tidak hanya menyajikan gambaran masyarakat utopis, tapi juga masyarakat distopis. Gambaran masyarakat distopis terlihat dari kenyataan bahwa dibalik kebahagiaan dan keceriaan serta keriangan yang sempurna dan suasana yang aman di kota Omelas tersimpan sesuatu yang miris, sebuah tindakan yang tak beradab dan tak manusiawi. Segala kebahagiaan, keceriaan, keriangan dan keamaan yang sempurna itu rupanya harus mengorbankan seorang anak kecil. Anak kecil itu dikurung dalam ruangan kecil pengap dan gelap di ruang bawah tanah kota. Penduduk Omelas mengetahui apa yang dialami anak itu, namun sebagian besar lebih memilih tidak peduli bahkan malah mengamini kebiadaban itu karena mereka meyakini bahwa kebahagiaan dan kelanjutan hidup mereka yang sempurna bergantung pada penderitaan yang dialami si anak. Mereka percaya harus ada seseorang yang dikorbankan agar kesejahteraan dapat diraih. Anak itu menjadi serupa tumbal demi 
kepentingan mereka bersama. Walau demikian, masih ada sebagian penduduk Omelas yang merasa terpukul hati nurani mereka atas keadaan yang menimpa bocah malang itu, mereka tidak dapat berkatakata, terdiam selama satu atau dua hari, lalu memutuskan pergi meninggalkan Omelas.

\section{DAFTAR PUSTAKA}

Byrne, Deirdre. 2012. Ursula.K. Le Guin's Lavinia: A Dia-logue with Classical Roman

Epic, diunduhdari http:// www.tandfonline.com/doi/ful 1/10.1080/10131752.2012.729 717? src=recsys diakses pada tanggal 14 Agustus 2017. Jam 11.10

Distopia, diunduh dari https:// id.wikipedia.org/wiki/Distopia, diakses pada tanggal 14 Agustus 2017. Jam 12.05

Kuper, Adam dan Jessica Kuper, 2008, Ensiklopedi Ilmu-il-mu Sosial, Jakarta: Pt. Raja Grafindo Persada.
Le Guin, Ursula, 1973, The Ones Who walk Away From Omelas, Vol 3, New Dimensions.

Mangoenkoesoemo, Yuka.D.N, 2012, Revisiting Michel Foucault, " Of Other Spaces, dalam http://culturalidiot.blogspot. co.id/2012/06/utopiaheterotopia-revisiting-michel.html, diakses 7 Nop 2017, jam 11.10

Trimarco, Paola. 1999. An Analysis of Lexical Opposition in Ursula Le Guin's "The Ones Who Walk Away from Omelas, " diunduh dari ht ps:// www.researchgate.net/publication/233432429_An_analysis_of_lexical_opposit ion = Le_Guin's the ones_who walk_away_from_Omelas 4 diakses pada tanggal 14 Agustus 2017. Jam 10.30

Utopia, diunduh dari https:// id.wikipedia. org/wiki/Utopia, diakses pada tanggal 14 Agustus 2017. Jam 12.30 